\title{
Molecular sexing of tucuxi dolphins (Sotalia guianensis and Sotalia fluviatilis) using samples from biopsy darting and decomposed carcasses
}

\author{
Haydée A. Cunha ${ }^{1,2}$ and Antonio M. Solé-Cava ${ }^{1}$ \\ ${ }^{1}$ Laboratório de Biodiversidade Molecular, Departamento de Genética, Instituto de Biologia, \\ Universidade Federal do Rio de Janeiro, Rio de Janeiro, RJ, Brazil. \\ ${ }^{2}$ Laboratório de Mamíferos Aquáticos, Departamento de Oceanografia, Instituto de Geociências, \\ Universidade do Estado do Rio de Janeiro, Rio de Janeiro, RJ, Brazil.
}

\begin{abstract}
We tested the zinc-finger sex chromosome-linked genes Zfx/Zfy and the sex-determining region $Y$ (Sry) genes for gender determination of biopsy samples from marine and riverine tucuxi dolphins (Sotalia guianensis and $S$. fluviatilis). We also evaluated the performance of these genes with decomposed carcasses, for which sexing cannot rely on the direct examination of the reproductive tract. Both systems proved reliable for sexing 46 fresh and decomposed samples, making them especially useful when biopsy darting is coupled with photo-identification studies.
\end{abstract}

Key words: cetaceans, remote sampling, sex determination, Sry, Zfx/Zfy.

Received: January 25, 2007; Accepted: May 23, 2007.

Few cetaceans exhibit easily observable sexual dimorphism. For most species, sex determination relies on the observation of the ventral region, which is a rare event in situ. The impracticality of morphological sex determination hinders a thorough understanding of important biological aspects. Molecular sexing can close this gap and can be coupled with low impact sampling such as biopsy darting, which has proved to be safe and minimally invasive for free-ranging cetaceans (IWC, 1991).

Two techniques, based on the polymerase chain reaction (PCR) amplification of the sex-determining region $\mathrm{Y}$ $(S r y)$ and the sex-specific regions of the zinc-finger sex chromosome-linked $Z f x$ and $Z f y$ genes, have proved to be fast, cheap and reliable for sex determination (Palsbøll et al., 1992; Bérubé and Palsbøll, 1996). Moreover, PCR techniques work well with degraded DNA, which is typical of samples from stranded carcasses, a major source of cetacean samples.

In this study we tested both techniques for the first time in tucuxi dolphins (genus Sotalia). This genus was considered monotypic until morphological and genetic studies demonstrated that the riverine (Sotalia fluviatilis) and the marine (Sotalia guianensis) dolphins were distinct species (Monteiro-Filho et al., 2002; Cunha et al., 2005).

Send correspondence to Antonio M. Solé-Cava. Departamento de Genética, Instituto de Biologia, Universidade Federal do Rio de Janeiro, Bloco A, CCS Ilha do Fundão, 21941-590 Rio de Janeiro, RJ, Brazil. E-mail: sole@ biologia.ufrj.br.
Many tucuxi populations are under human threat, but they are still considered "data deficient" by the International Union for the Conservation of Nature (2006) and the Brazilian Environmental Agency (Instituto Brasileiro de Meio Ambiente e Recursos Naturais Renováveis - IBAMA) (IBAMA, 2001).

We analyzed 36 S. guianensis samples of skin, muscle or liver, collected from stranded carcasses, by-caught specimens or through biopsy darting along the Brazilian coast ( $1^{\circ} 20^{\prime} \mathrm{S}$ and $25^{\circ} 31^{\prime} \mathrm{S}$ ) as well as $10 \mathrm{~S}$. fluviatilis skin biopsy samples obtained during a capture procedure in the Brazilian state of Amazonas ( $2^{\circ} 57^{\prime} \mathrm{S}, 64^{\circ} 48^{\prime} \mathrm{W}$ ), during which the dolphins were sexed by examination of their genital openings. The condition of the samples was graded according to the codes proposed by Geraci and Lounsbury (1993), with all biopsy samples qualifying as Code 1, while the condition of the remaining samples varied from Code 2 (fresh) to 4 (poor). We also analyzed six $S$. guianensis sun-dried genitals obtained from the Ver-o-Peso market, in the Brazilian State of Pará, which were assessed as Code 5 (mummified).

Total genomic DNA of all samples was extracted by the phenol-chloroform procedure of Sambrook et al. (1989). We initially optimized and validated the $Z f x / Z f y$ and Sry sexing techniques in 10 specimens each of $S$. guianensis and $S$. fluviatilis whose gender was known. The nuclear DNA Zfx/Zfy and Sry regions were PCR-amplified in separate reactions using the ZFXY582, ZFX923 and ZFY767 primers (Bérubé and Palsbøll 1996) and the 
SRY593 and SRY764 primers (Palsbøll et al. 1992), and the PCR products mixed before electrophoresis in $2 \%(\mathrm{w} / \mathrm{v})$ agarose gels. Two positive controls were used for sexing the dolphins with the Sry system: (1) PCR amplification of the mitochondrial control region, as described by Palsbøll et al. (1992), using the primers Dlp 1.5 (modified from Pichler et al., 1998) and H00034 (Rosel et al., 1994); (2) amplification of the $Z f x$ or $Z f y$ band in the sample. Negative controls were included in all experiments. Amplifications were carried out in $20 \mu \mathrm{L}$ reactions containing $0.20 \mathrm{mM}$ dNTPs, $2 \mathrm{mM} \mathrm{MgCl}_{2}, 0.5 \mu \mathrm{M}$ of each primer and 1 unit of Taq polymerase (Amersham Pharmacia). The PCR cycling conditions were $3 \mathrm{~min}$ at $94{ }^{\circ} \mathrm{C}$, followed by 38 cycles of $1 \mathrm{~min}$ at $92^{\circ} \mathrm{C}, 1 \mathrm{~min}$ at $50^{\circ} \mathrm{C}$ and $1 \mathrm{~min}$ at $72{ }^{\circ} \mathrm{C}$; plus a 5 min extension at $72{ }^{\circ} \mathrm{C}$.

Nucleotide sequences of the $Z f x$ and $Z f y$ regions of three $S$. fluviatilis and seven $S$. guianensis males were deposited in the GenBank under accession numbers DQ409819 and DQ409820.

Our results show that the Zfx/Zfy and Sry regions can be reliably used for sexing both Sotalia species, reproducing exactly the expected patterns (Figure 1) and unambiguously identifying the sex of all dolphins tested in the control runs.

All S. fluviatilis and $67 \%$ of S. guianensis male samples produced two bands of about $380 \mathrm{bp}$ and $230 \mathrm{bp}$ during the amplification of the $Z f x / Z f y$ regions, corresponding, respectively, to the fragments present in the $\mathrm{X}$ and $\mathrm{Y}$ chromosomes, and a single $170 \mathrm{bp}$ band in the amplification of the Sry region (Figure 1). In the two remaining S. guianensis male samples, the $Z f x$ bands were not observed, but the presence of the Zfy and Sry fragments allowed unambiguous sex determination. The female expected pattern, a single 380 bp Zfx band and no Zfy or Sry product, was observed in all female samples used in the test phase. All samples successfully amplified the mitochondrial control region.

Once the technique was proven valid and reliable for both Sotalia species, we analyzed samples from $26 \mathrm{~S}$. guianensis dolphins of unknown gender. The biopsies and the Ver-o-Peso samples were easily sexed, revealing six males and three females. Of the 17 carcass samples, 13

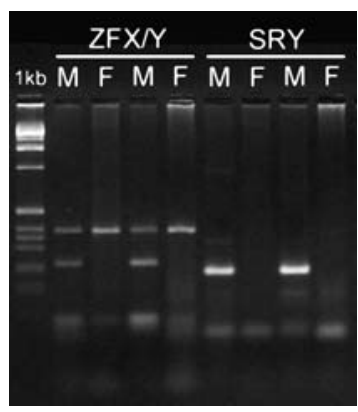

Figure 1 - Sex determination patterns for male (M) and female (F) Sotalia samples, using the $Z f x / Z f y$ and Sry primer systems.
(76\%) could be directly sexed (six males and seven females), and four samples amplified the mtDNA but not the sex genes. We conducted two series of experiments to verify whether PCR failure was due to a low number of single-copy DNA molecules of adequate size for amplification, or the presence of PCR inhibitors. To verify if PCR failure was due to DNA degradation, we performed serial dilutions of the DNA template of a male and a female positive control. The PCR amplifications using template dilutions of up to 1:10000 were successful for the mitochondrial control region, the $Z f y$ and the Sry genes, whereas the $Z f x$ band could not be amplified in template dilutions greater than 1:200 (Table 1).

The inhibition hypothesis was initially investigated using a tenfold dilution of template DNA so that any contaminants would become too diluted to inhibit the PCR. No PCR bands were observed using any of the diluted templates. Next, we mixed $1 \mu \mathrm{L}$ of the DNA from a male that amplified the $Z f x$ and $Z f y$ genes with $9 \mu \mathrm{L}$ of each of the four samples that failed to amplify. A 1:10 dilution of the DNA of the positive male in DNA from another positive male and in water were used as positive controls. Although

Table 1 - Results of dilution and inhibition experiments. Key: A, B, C and $\mathrm{D}$, problematic samples; F, positive female; $\mathrm{M}$, positive male.

\begin{tabular}{lcccc}
\hline Treatments & Zfx & Zfy & Sry & mtDNA \\
\hline Dilution experiment & & & & \\
$M+$ water $(1: 100)$ & + & + & + & + \\
$M+$ water $(1: 500)$ & - & + & + & + \\
$M+$ water $(1: 1,000)$ & - & + & + & + \\
$M+$ water $(1: 5,000)$ & - & + & + & + \\
$M+$ water $(1: 6,000)$ & - & + & + & + \\
$M+$ water $(1: 10,000)$ & - & + & + & + \\
$M+$ water $(1: 20,000)$ & - & - & - & - \\
$F+$ water $(1: 100)$ & + & & & + \\
$F+$ water $(1: 200)$ & + & & & + \\
$F+$ water $(1: 400)$ & - & & & + \\
$F+$ water $(1: 1,000)$ & - & & & + \\
$F+$ water $(1: 10,000)$ & - & & & + \\
\hline Inhibition experiment & & & & \\
$M+M(1: 10)$ & + & + & + & + \\
$M+F(1: 10)$ & - & + & + & + \\
$M+$ water $(1: 10)$ & - & + & + & + \\
$M+$ A* & - & + & + & + \\
$M+$ B* & - & + & + & + \\
$M+$ C* & - & + & + & + \\
$M+$ D* & - & & + & + \\
\hline B or D + water $(1: 10)$ & - & & & + \\
\hline
\end{tabular}

*Each tested with three different dilutions: $0.5 \mu \mathrm{L}$ of M diluted in i) $4.5 \mu \mathrm{L}$ problematic sample; ii) $2.3 \mu \mathrm{L}$ problematic sample $+2.3 \mu \mathrm{L}$ water; and iii) $1 \mu \mathrm{L}$ problematic sample $+3 \mu \mathrm{L}$ water. All dilutions gave the same result. 
only the positive male/positive male treatment amplified the $Z f x$ band, the Zfy, Sry and control region bands were observed in all other treatments (Table 1). Therefore, we conclude that the lack of amplification in those four samples was DNA degradation. Hence, the most parsimonious explanation is that the four samples that failed to amplify the sex linked markers were females, since $Z f x$ amplification was much more sensitive to template concentration than both the mtDNA and the Y-specific genes. This indicates that the mtDNA control region can be consistently used as a positive control for the Sry system in Sotalia species. It is advisable, however, that a dilution experiment be conducted prior to choosing this marker as a positive control in other species.

The Zfx/Zfy and Sry systems have been used by a large number of workers carrying out research on cetacean species, e.g., Sry by Rosenbaum et al. (2002), Zfx+Sry by Harlin et al. (2003), and Möller and Beheregaray (2004), $Z f y+S r y$ by Gowans et al. (2000), and Zfx+Zfy by Pichler et al. (1998) and Escorza-Treviño and Dizon (2000). Their applicability across the taxonomic spectrum is suggested by the high evolutionary conservativeness of Zfx/Zfy (Morin et al., 2005). Indeed, all Sotalia sequences were identical and $99.4 \%$ similar to those of Phocoena phocoena, which belongs to a different Family.

In summary, the technique described in this paper is fast, reliable and works on most degraded samples, including sun-dried tissues. This is particularly useful since decaying carcasses are a major source of material for Sotalia and other cetaceans, especially in tropical regions. Undoubtedly, molecular sexing will offer new insights into Sotalia social structure and improve conservation and management decisions.

\section{Acknowledgments}

We are thankful to Vera M. F. da Silva (INPA-Brazil); José Lailson Brito Jr, Alexandre Azevedo, Ana Bernadete Fragoso (MAQUA/UERJ-Brazil), Regina C. Zanelatto (UFPR-Brazil) and Manuel Furtado Neto (UFCE-Brazil) for providing tissue samples. We are also indebted to Fernando A. Monteiro and Phill Watts, for comments on an early version of the manuscript. This work is part of the Doctoral thesis of HAC and was financially supported by the Brazilian agencies CNPq and FAPERJ. Biopsy was authorized under permits 022/01/CMA/ IBAMA and IBAMA 02001.0002344/96-11. Genetic analyses were performed under permit 03/2005-IBAMA.

\section{References}

Bérubé M and Palsbøll P (1996) Identification of sex in cetaceans by multiplexing with three $Z f x$ and $Z f y$ specific primers. Mol Ecol 5:283-287.
Cunha HA, da Silva VMF, Lailson-Brito Jr, Santos MCO, Flores PAC, Martin AR, Azevedo AF, Fragoso ABL, Zanelatto RC and Solé-Cava AM (2005) Riverine and marine ecotypes of Sotalia dolphins are different species. Mar Biol 148:449457.

Escorza-Treviño S and Dizon AE (2000) Phylogeography, intraspecific structure and sex-biased dispersal of Dall's porpoise, Phocoenoides dalli, revealed by mitochondrial and microsatellite DNA analyses. Mol Ecol 9:1049-1060.

Geraci JR and Lounsbury VJ (1993) Marine Mammals Ashore: A Field Guide for Strandings. $1^{\text {st }}$ edition. Texas A \& M University, Texas, $372 \mathrm{pp}$.

Gowans S, Dalebout ML, Hooker SK and Whitehead H (2000) Reliability of photographic and molecular techniques for sexing northern bottlenose whales (Hyperoodon ampullatus). Can J Zool 78:1224-1229.

Harlin AD, Markowitz T, Baker CS, Würsig B and Honeycutt RL (2003) Genetic structure, diversity, and historical demography of New Zealand's dusky dolphin (Lagenorhynchus obscurus). J Mammal 84:702-717.

Hoelzel AR and Donovan GP (1991) Genetic Ecology of Whales and Dolphins. Report of the International Whaling Commission, Special Issue 13. IWC, Cambridge, $311 \mathrm{pp}$.

IBAMA (2001) Mamíferos Aquáticos do Brasil - Plano de Ação (Versão II). IBAMA, Brasília, 79 pp.

Möller LM and Beheregaray LB (2004) Genetic evidence for sex-biased dispersal in resident bottlenose dolphins (Tursiops aduncus). Mol Ecol 13:1607-1612.

Monteiro-Filho ELA, Monteiro LR and Reis SF (2002) Skull shape and size divergence in dolphins of the genus Sotalia: A tridimensional morphometric analysis. J Mammal 83:125-134.

Morin PA, Nestler A, Rubio-Cisneros NT, Robertson KM and Mesnick S (2005) Interfamilial characterization of a region of the $Z f x$ and $Z f y$ genes facilitates sex determination in cetaceans and other mammals. Mol Ecol 14:3275-3286.

Palsbøll PJ, Vader A, Bakke I and Raafat El-Gewely M (1992) Determination of gender in cetaceans by the polymerase chain reaction. Can J Zool 70:2166-2170.

Pichler FB, Dawson SM, Slooten E and Baker CS (1998) Geographic isolation of Hector's dolphin populations described by mitochondrial DNA sequences. Conserv Biol 12:676682.

Rosel PE, Dizon AE and Heyning JE (1994) Genetic analysis of sympatric morphotypes of common dolphins (genus Delphinus). Mar Biol 119:159-167.

Rosenbaum HC, Weinrich MT, Stoleson SA, Gibbs JP, Baker CS and DeSalle R (2002) The effect of differential reproductive success on population genetic structure: Correlations of life history with matrilines in humpback whales of the Gulf of Maine. J Hered 93:389-399.

Sambrook J, Fritsch EF and Maniatis T (1989) Molecular Cloning: A Laboratory Manual. $2^{\text {nd }}$ edition. Cold Spring Harbor Laboratory Press, New York, 1659 pp.

\section{Internet Resource}

IUCN Red list of threatened species (2006) IUCN, Gland, Switzerland. http://www.iucn.org/themes/ssc/redlist.htm. (November 26, 2006).

Associate Editor: João Stenghel Morgante 